3. Анчишкин А.И. Прогнозирование роста социалистической экономики / А.И. Анчишкин. М. : Изд-во "Экономика", 1973. - 294 с.

4. Боронос В.Г. Методологічні засади управління фінансовим потенціалом території : монографія / В.Г. Боронос. - Суми : Вид-во Сум. ДУ, 2011. - 310 с.

5. Воронкова А.Э. Стратегическое управление конкурентоспособным потенциалом предприятия: диагностика и организация : монография / А.Э. Воронкова. - Луганск : Изд-во Восточно-украинского НУ, 2000. - 315 с.

6. Гетьман О.О. Економічна діагностика : навч. посібн. / О.О. Гетьман, В.М. Шаповал. - К. Вид-во "Центр навч. літ-ри", 2007. - 307 с.

7. Джаин И.О. Оценка трудового потенциала : монография / И.О. Джаин. - Сумы : Изд-во ИТД "Университетская книга", 2002. - 250 с.

8. Іщук С.О. Виробничий потенщіал промислових підприсмств: проблеми формування розвитку : монографія / С.О. Іщук. - Львів : Вид-во ІРД НАН України, 2006. - 278 с.

9. Князь С.В. Формування і використання трансферного потенціалу інноваційного розвитку підприємства : автореф. дис. на здобуття наук. ступеня д-ра екон. наук / С.В. Князь: МОН, моку підприємства : автореф. Дис. на здобуття наук. ступеня д-ра ес.
лоді та спорту України, НУ "Львівська політехніка", 2013. - 52 с.

10. Кун Т. Структура научных революций / Т. Кун. [Электронный ресурс]. - Доступный с http://vikent.ru/enc/1345/.

11. Лапин Е.В. Экономический потенциал предприятия : монография / Е.В. Лапин. - Сумы : Изд-во ИТД "Университетская книга", 2004. - 359 с.

12. Лукинов И. Аграрный потенциал: исчисление и использование / И. Лукинов, А. Онищенко, Б. Пасхавер // Вопросы экономики : сб. науч. тр. - 1988. - № 1. - С. 24-27.

13. Мосійчук І.В. Ресурсний потенціал соціальної сфери України та економічний механізм його відтворення : автореф. дис. на здобуття наук. ступеня канд. екон. наук / І.В. Мосійчук: МОН України, Відкритий Міжнар. університет розвитку людини "Україна", 2015. - 20 с.

4. Новікова М.М. Методологічне забезпечення системи управління трудовим потенціалом промислових підприємств : автореф. дис. на здобуття наук. ступеня д-ра екон. наук / М.М. Новікова: МОН України, Харківський НЕУ, 2010. - 36 с

15. Промисловий потенціал України: проблеми та перспективи структурно-інноваційних трансформацій / відпов. ред. Ю.В. Кіндзерський. - К. : Вид-во Ін-ту економіки та прогнозування НАН України, 2007. - 408 с.

16. Ревуцкий Л.Д. Потенциал и стоимость предприятия / Л.Д. Ревуцкий. - М. : Изд-во "Перспектива", 1997.- 124 с.

17. Свободин В.И. Производственный потенциал сельскохозяйственного предприятия и оценка эффективности его использования / В.И. Свободин // Вестник статистики : сб. науч. тр. 1984. - № 10. - C. $20-25$

18. Соціально-економічний потенціал сталого розвитку України та їі регіонів: національна доповідь / за ред. Е.М. Лібанової, М.А. Хвесика. - К. : Вид-во ДУ ІЕПСР НАН України, 2014. $775 \mathrm{c}$.

19. Федонін О.С. Потенціал підприємства: формування та оцінка : навч. посібн. / О.С. Федонін, І.М. Рєпіна, О.І. Олексюк. - К. : Вид-во КНЕУ, 2005. - 261 с.

20. Черников Д.А. Эффективность использования производственного потенциала и конечные народнохозяйственные результаты / Д.А. Черников // Экономические науки : сб. науч. тр. 1981. - № 10. - С. $89-97$.

21. Шевченко Д.К. Проблемы эффективности использования экономического потенциала / Д.К. Шевченко. - Владивосток : Изд-во Дальневост. ун-та, 1984. - 187 с.

22. Шумська С.С. Фінансовий потенціал України: методологія визначення та оцінки С.С. Шумська // Фінанси України : журнал. - 2007. - № 15. - С. 55-64.

Надійшло до редакції 20.01.2016 p.

Станасюк Н.С., Глушко О.В. Генезис понятийно-категориального аппарата исследования промышленного потенциала

Проведен анализ трактовки понятия "потенциал" в научной литературе в разные временные периоды. На этой основе определены ресурсный, гипотетический, систем. особенности трактовки понятия "потенциа" в соответствии с указанными подходай. Установлена взаимосвязь между различными этапами развития экономики и научными исследованиями. Предпринята попытка обобщения различных концептуальных подходов к дефиниции "потенциал" и на этой основе рассмотрено содержательное наполнение категории "промышленный потенциал".

Ключевые слова: потенциал, ресурс, возможность, система, результат, промышленный потенциал.

Stanasyuk N.S., Hlushko O.V. The Genesis of Conceptual Categorical Research Staff of Industrial Potential

The analysis of the interpretation of the term "potential" in the scientific literature in different time periods is made. On this basis, a resource, hypothetical, systematic and effective approaches to the justification of its economic nature are grounded. The features of interpretations of the term 'potential' in the context of these approaches are determined. The interrelation between the different stages of economic development and scientific research is established. The authors attempt to generalize different conceptual approaches to the definition of 'potential' and, on that basis, meaningful content of the category 'industrial potential' is considered.

Keywords: potential, resource, opportunity, system, result, industrial potential.

УДК 330.320

\section{ЗАБЕЗПЕЧЕННЯ ЕКОНОМІЧНОЇ БЕЗПЕКИ ПІДПРИЄМСТВА}

\section{НА ОСНОВІ ІННОВАЦІЙНОГО РОЗВИТКУ}

\section{І.В. Цюпко ${ }^{1}$, О.Й. Жабинець ${ }^{2}$, О.Р. Волошин ${ }^{3}$}

Розглянуто тенденції інноваційного розвитку мікросередовища української економіки. Сучасний етап соціально-економічного розвитку країни, передусім, характеризується вкрай незначним впливом інноваційних факторів на розвиток економіки через існування багатьох бар'єрів, які уповільнюють ріст ефективності застосування інноваційних технологій. Наведено ризики та обмежувальні мікроекономічні умови прогнозного періоду, які сформувались у 2011-2014рр. і продовжують залишатися проблемними на цей час. Проаналізовано наслідки процесів фінансування на обсяги і структуру інноваційної діяльності підприємств, на конкурентоспроможність вітчизняної продукції. Слабкість державної політики у науково-технічних та інноваційних сферах, недоліки у визначенні державних пріоритетів, незадовільна ситуація з їх забезпеченням і реалізацією гальмують вплив інновацій на розвиток економіки загалом та підприємств зокрема. Запропоновано комплекс заходів з боку держави щодо проведення ефективно інновашійно-інвестиційної політики для забезпечення економічної безпеки країни.

Ключові слова: економічна безпека, інноваційний розвиток, інноваційна активність, фінансування інноваційних робіт, інвестиційні ресурси.

Постановка проблеми. Метою дослідження $є$ розгляд особливостей, обгрунтування та реалізації інноваційної діяльності підприємства в умовах забезпечення його економічної безпеки.

Аналіз останніх досліджень і публікацій. Питання інноваційної діяльності на рівні підприємства дослідили такі науковці, як: І. Алексєєв, В. Александрова, О. Алимов, Ю. Бажал, О. Барановський, О. Василик, А. Гальчинський, А. Гойко, М. Долішній та ін. Потребу інноваційного розвитку підприємств обгрунтували у своїх розробленнях А. Гриньов, Т. Дудар, А. Загородній, В. За-

доц. І.В. Цюпко, канд. екон. наук - Львівський ДУ внутрішніх справ;

доц. О.Й. Жабинець, канд. екон. наук - Львівський дУ внутрішніх справ;

доц. О.Р. Волошин, канд. фіз.-мат. наук - Львівський ДУ внутрішніх справ

2. Продуктивні сили 
харченко, В. Чубай. Існування тісного зв'язку "інновації-конкурентоспроможність-економічна безпека" досліджено у працях С.А. Іванова, С.В. Лабунської, Л.С. Шкарлета, наголошуючи, що інновації $є$ основою забезпечення економічної безпеки підприємства.

Мета дослідження. Обгрунтування теоретичних підходів щодо сутності інноваційної діяльності національних підприємств з метою забезпечення економічної безпеки.

Виклад основного матеріалу. Рівень інноваційної безпеки характеризується станом розвитку науково-технічного потенціалу підприємства, його спроможністю на достатньому рівні генерувати позитивні зрушення в економіці, які є потрібними для забезпечення та підтримки конкурентоспроможності вітчизняної продукції на внутрішньому і світових ринках. Процеси фінансування значно впливають на обсяги і структуру інноваційної діяльності підприємств.

У структурі фінансування інноваційної діяльності протягом 2014 р. відбулись певні зрушення. Так, частка витрат на дослідження і розробки в загальному обсязі витрат на здійснення інноваційної діяльності зросла від 10,6 до 16,1 \% (абсолютний показник зріс від 612,3 до 992,9 млрд грн). Зросла також частка витрат на придбання машин, обладнання, інших основних фондів, пов'язаних із здійсненням інноваційної діяльності. Із 6,2 млрд грн, які у 2014 р. витрачено підприємствами на інноваційні роботи, 3,5 млрд грн $(56,5 \%)$ направлено на фінансування процесових інновацій, тобто створення та впровадження у виробництво нових технологічних процесів (у 2013 р. - 3,1 млрд грн або $54,8 \%$ ). На дослідження і розробки, що є ключовим фактором технологічного розвитку, підприємства витратили 992,9 млн грн або 16,1\% обсягу інноваційних витрат. У 2014 р. основним джерелом фінансування інноваційних робіт були власні кошти підприємств, частка яких у загальному обсязі фінансування технологічних інновацій становила $84,6 \%$, що на $3,1 \%$ менше порівняно 3 2013 р. [5]. Обсяг фінансування інноваційних робіт за рахунок коштів державного бюджету збільшився майже на $75 \%$ і становив 114,4 млн грн (у 2014 р. 28,1 млн грн). При цьому його частка становила 1,9 \% проти 0,5 \% у 2013 р.

Отже, спостерігається незначне збільшення фінансування інноваційної діяльності, однак воно не спроможне забезпечити належний рівень іiі розвитку. Прикро, але в інноваційній діяльності, як і в інших сферах діяльності, набула поширення практика ігнорування законодавства або призупинення дії статей законів, які стосуються фінансування інноваційної діяльності. Негативним моментом $\epsilon$ те, що значення окремих стимулятивних показників безпеки не мають додаткового приросту. Такими показниками є незначна кількість підприємств, які впроваджують інновації, мала кількість винаходів, відсутність платоспроможного попиту на інноваційну продукцію.

Питома вага інноваційної продукції в загальному обсязі промислового виробництва в Україні становить менше 7 \%, а інновації впроваджують не більше $14 \%$ промислових підприємств. Якщо у 2010 р. на 100 тис. населення в Україні було зареєстровано майже 35 винаходів, то сьогодні - усього близько 3. Причиною цього можна назвати надзвичайно високу ціну патентування винахо- дів, внаслідок чого не кожне підприємство здатне оплачувати ці процеси. Тому у сфері наукового обслуговування в Україні працює всього близько $5 \%$ підприємницьких структур, тобто не більше ніж 1500 малих підприємств.

Іншим істотним чинником, який стримуватиме збільшення інноваційної активності підприємств у найближчій перспективі, $є$ відсутність платоспроможного попиту на інноваційну продукцію. Це певною мірою зумовлене недостатніми темпами становлення сучасного і масштабного ринку інноваційної продукції в Україні, а також неспроможністю більшості вітчизняних товаровиробників бути рівноправними партнерами на міжнародному ринку інноваційних товарів і послуг. Державу потрібно розглядати як координатора та творця інноваційної безпеки, яка має активізувати розвиток ринково орієнтованих механізмів стимулювання діяльності інноваційного розвитку підприємства [6].

Згідно 3 даними І. Шовкун, в Україні сукупна питома вага видів діяльності, що належать до високотехнологічного і середньотехнологічного рівня розвитку, менша за $13 \%$. Перспективи поширення цих видів діяльності залежать від обсягів інвестування в їхній розвиток, проте в них вкладається менше $5 \%$ від інвестиційних ресурсів економіки, що не відповідає не тільки їх ролі в економіці, але й потребам простого відтворення виробничого потенціалу [8]. Складаються умови, що ведуть до згортання цих видів діяльності.

Проведений аналіз інноваційної активності свідчить, що головною причиною низької інноваційної активності підприємств потрібно визнати відсутність довгострокових мотивацій організації високопродуктивної інноваційної діяльності. Інноваційна діяльність $є$ малоприбутковою (низькорентабельною) та більш ризикованою, порівняно з іншими видами діяльності. Завданням держави $\epsilon$ створення ефективної та адекватної вимогам сьогодення системи підтримки інноваторів, яка давала б змогу здійснювати високопродуктивну інноваційну діяльність хоча б у пріоритетних сферах економіки.

Разом з тим світовий досвід підтверджує, що інноваційна сфера, особливо у країнах з перехідною економікою, не спроможна "одужати" тільки завдяки саморегулятивним механізмам. Необхідне впровадження відповідних адекватних державних програм, спрямованих на поліпшення інвестиційно-інноваційного клімату і підвищення ефективності інноваційної діяльності [9]. Держава має підтримувати ті інновації, що вкладаються у виробництва вищих технологічних укладів або поліпшують ресурсну базу економіки (сприяють екологізації виробництва, ведуть до збільшення людського капіталу, забезпечують впровадження проектів 3 енергозбереження тощо).

Протягом останніх років державна економічна політика була націлена на підтримку експорту, основна частина якого в нашій країні забезпечується сировиною та продукцією $з$ незначним ступенем перероблення. Внаслідок цього у привабливішому економічному становищі опинилися виробництва нижчих технологічних укладів, які характеризуються капіталомісткістю, екологічною небезпечністю та низьким рівнем розроблення і впровадження інвестицій. Але пріоритетний розвиток сировинних галузей, що були і залишаються провідними у вітчизняній економіці, не здатний вирішити завдання стійкого випереджувального економічного піднесення. Сировинні галузі - це основа індустріальної економіки України, але не головна ії рушійна сила. 
Сучасною академічною наукою доведено, що вихід економіки України на траєкторію випереджувального розвитку має характеризуватися не тільки збільшенням темпів економічного зростання, а й докорінною структурною перебудовою, збільшенням частки високотехнологічних галузей [9]. Під час вироблення стратегії подальшого становлення інноваційної системи та заходів посилення ролі в цьому процесі промислових підприємств потрібно враховувати, що в Україні вирішення проблеми інноваційного розвитку має певні особливості. Наша держава пережила нечуване падіння виробництва, катастрофічне зростання інфляції, жорстку кризу платежів, стрімке збільшення безробіття, що призвело до стрімкого зниження рівня життя населення. "Шокова" терапія не дала позитивних наслідків, оскільки структурно здеформована, мілітаризована, неефективна та витратна економіка була до цього не готова. Досить довго не фінансувалися навіть критично необхідні інвестиції, не кажучи вже про інновації. Задля активізації інноваційної діяльності корпоративного сектору потрібно розробити сучасну систему стимулювання розробок і впровадження промислових інновацій. 3 огляду на нинішню модель трансформаційних перетворень, вважаю, що основним елементом цієї системи мають стати такі стимули, що безпосередньо впливають на економічний (передусім фінансовий) стан об'єктів регулювання.

Активізувати процес впровадження інноваційних проектів має сучасний механізм надання пільг (зокрема податкових) промисловим підприємствам. Закордонний досвід свідчить, що це є дієвим важелем підтримки такої діяльності Слід дедалі активніше створювати (та заохочувати вже створені) технопарки, технологічні інкубатори, інноваційні виробництва, насамперед у пріоритетних галузях. Зокрема, це: радіоелектронна та приладобудівна промисловість, сільськогосподарське машинобудування, важке машинобудування, суднобудування, літакобудування, хімічна промисловість, а також "споживчі" галузі (легка, харчова, меблева промисловість).

Важливим науково-практичним завданням $є$ вироблення методичних підходів щодо стимулювання інноваційної активності промислових підприємств. Чинники і тенденції, що впливатимуть на стан інноваційної активності підприємств у коротко- та середньостроковій перспективі, зводяться до такого. Аналіз показав, що триває спад інноваційної активності за умов пожвавлення економічного зростання. Це свідчить про те, що у вітчизняній економіц не забезпечено зв'язку науки, технологій та виробництва, який мав би стимулювати розроблення та впровадження інновацій. Цей чинник матиме вплив і протягом найближчих років.

Іншим значним чинником, який стримуватиме збільшення інноваційної активності підприємств у найближчій перспективі, є відсутність платоспроможного попиту на інноваційну продукцію. Це певною мірою зумовлене недостатніми темпами становлення сучасного і масштабного ринку інноваційної продукції в Україні. Слабка робота щодо формування нових галузей виробництва зумовлена низькими обсягами і деформованою структурою інвестицій. Тривале скорочення внутрішнього інноваційного попиту з боку галузей високих технологій, зростання фінансування досліджень з боку іноземних замовників змушують вітчизняних розробників збувати свою науково-технічну продукцію іноземним фірмам на початкових етапах інноваційного циклу, закриваючи цим самим шлях до реалізації економічного потенціалу нововведень на користь України.

Очевидно, що промислові підприємства не зможуть вкладати ресурси у розроблення та впровадження інновацій доти, поки не вирішать власних інвестиційних проблем. Не секрет, що інвестиційні ресурси України виснажені і не забезпечують ефективного розширеного відтворення. Зношеність основних фондів у деяких галузях сягає 50 \%, підприємства використовують вкрай застарілу матеріально-технічну базу, більшість обігових коштів спрямовуються не на оновлення обладнання, а на його ремонт і підтримку хоча б мінімальної здатності створювати нову вартість. Більшість підприємств у найближчі роки не зможуть займатися високопродуктивною інноваційною діяльністю.

Інвестиційні ресурси юридичних осіб значною мірою сформовані завдяки амортизаційним відрахуванням. Тому апарат держави до розроблення амортизаційної політики має підходити особливо уважно. Однак державна амортизаційна політика не відповідає вимогам сьогодення і $є$ вкрай недосконалою.

Висновки. Значну частину амортизаційних відрахувань використовують не за своїм економічним призначенням. Кошти амортизації витрачають не на відтворення основного капіталу, а на споживання ("проїдання"). Норми прискореної амортизації, що фактично нав'язуються підприємствам, $є$ невигідними для збиткових підприємств. Прискорена амортизація не дуже вигідна і в умовах відсутності платоспроможного попиту, коли зростання собівартості продукції веде до відмови споживачів від користування цією продукцією.

Отже, одним з основних завдань держави є впровадження заходів щодо регулювання інноваційного розвитку, які будуть доповнювати ринкові механізми і впливати на інноваційну безпеку підприємства:

1. Запровадження механізму надання істотних пільг промисловим підприємствам, що розробляють і впроваджують інновації та виробляють інноваційну продукцію.

2. Без істотного покращення інвестиційного клімату активізація інноваційної діяльності промислових підприємств, а разом з нею - і перехід економіки на інноваційну модель розвитку, $\epsilon$ неможливою.

3. У зв'язку з відсутністю попиту на інноваційну продукцію потрібно забезпечити державне замовлення на інноваційну продукцію, а також поширити практику прямого державного фінансування інноваційних інвестицій у рамках реалізації програм модернізації промисловості.

4. Розробити методичні підходи щодо експертного оцінення рівня інноваційності продукції, що випускається підприємством, і загального технікотехнологічного рівня виробництва 3 метою вирішення питання про можливість його державної підтримки.

\section{Література}

1. Губський Б.В. Економічна безпека України: методологія виміру, стан і стратегія забезпе: монографія / Б.В. Губський. - К. : Вид-во "Укрархбудінформ", 2010. - 121 с.

2. Косевцов В.О. Національна безпека України: теорія, реальність, прогноз / В.О. Косевцов. К. : Вид-во "Лібра", 2007. - 78 с.

3. Методичні рекомендації щодо оцінки рівня економічної безпеки України / за ред. А.І. Сухорукова. - К. : Вид-во НІПМБ, 2003. - 64 с. 
4. Наукова та інноваційна діяльність в Україні : стат. зб. / Держкомстат. - К. : Вид-во "Лібpa", 2013. $-360 \mathrm{c}$.

5. Основы экономической безопасности / под ред. Е.А. Олейникова. - М. : Изд-во "Бизнессинтез", 1997. - 288 с.

6. Петрина Н. Базові умови створення інноваційної моделі розвитку економіки України / Н Петрина // Економіка України : політико-екон. журнал. - 2013. - № 8. - С. 35-40.

7. Шовкун І. Інституційне підгрунтя інноваційного розвитку: Міжнар. досвід та уроки для транзитних економік / І. Шовкун // Економічна теорія : зб. наук. праць. - 2012. - № 3. - С. 60-74. 8. Роль держави у довгостроковому економічному зростанні : монографія / за ред. д-ра екон. наук Б.С. Кваснюка. - К. : Вид-во Ін-ту екон. прогнозув. - Харків : Вид-во "Форт", 2003. $424 \mathrm{c}$.

9. Шабанова М.М. Организационно-экономические механизмы управления в системах предпринимательства / М.М. Шабанова. - СПб. : Изд-во С.-Петерб. ГУ экономики и финансов, 2011. $-320 \mathrm{c}$

10. Яковлєв А.Т. Управління інвестиційною та інноваційною діяльністю на основі проектного аналізу : навч. посібн. / А.Т. Яковлєв. - К. : Вид-во УАДУ, 2012. - 236 с.

Надійшло до редакції 11.03 .2016 p.

Цюпко И.В., Жабинец О.Й., Волошин А.Р. Обеспечение экономической безопасности предприятия на основании инновационного развития

Рассмотрены тенденции инновационного развития микросреды украинской экономики. Современный этап социально-экономического развития Украины, в первую очередь, характеризуется незначительным влиянием инновационных факторов на развитие экономики из-за существования численных барьеров, которые замедляют рост эффективности инновационных технологий. Приведены риски и ограничительные микроэкономические условия прогнозного периода, которые сформировались в 20112014 гг. и продолжают оставаться проблемными в наше время. Проанализированы следствия процессов финансирования на объем и структуру инновационной деятельности предприятий, на конкурентоспособность отечественной продукции. Слабость государственной политики в научно-технических и инновационных сферах, недостатки в определении государственных приоритетов, неудовлетворительная ситуация с их обеспечением и реализачией тормозят влияние иннований на развитие экономики в целом и печением и реализацией тор

Предложен комплекс мер со стороны государства для проведения эффективной инновационно-инвестиционной политики с целью обеспечения экономической безопасинновационно-ин
ности страны.

Ключевые слова: экономическая безопасность, инновационное развитие, инновационная активность, финансирование инновационных работ, инвестиционные ресурсы.

Tsiupko I.V., Zhabynets O.Yo., Voloshyn O.R. Providing Economic Security for the Enterprise Based on Innovative Development

The innovative development tendencies of microenvironment of Ukraine's economy have been examined in detail. The present stage of social and economic development of Ukraine is primarily characterized by insignificant impact of innovative factors affecting the economic development because of the existence of many obstacles that slow down the growth of effectiveness of the innovative technology applications. The risks and restrictive microeconomic measures of the forecast period, formed in 2011-2014, have been exemplified and are still problematic nowadays. The results of funding the volume and structure of enterprising innovation and the competitiveness of domestic products have been analyzed. Among negative aspects that slow down the influence of innovations on economic development in general and businesses in particular are the following: the weakness of the state policy in the fields of science and technology and inovation; drawback in inten no-win situation with their providing and marketing. A range of state measures to conduct the effective innovative investment policy to ensure the economic security of the country has been proposed.

Keywords: economic security, innovative development, innovative activity, funding the innovative works, investment resources.
УДК 316.334.2

\section{АНАЛІЗ ПІДХОДІВ І МЕТОДІВ ОЦІНЮВАННЯ ЕКОНОМІЧНО БЕЗПЕКИ ТУРИСТИЧНОГО ПІДПРИЕМСТВА}

о.Я. Щербан ${ }^{1,2}$

Проаналізовано основні підходи та методи щодо оцінювання економічної безпеки туристичного підприємства. Доведено, що в нинішніх умовах конкуренції і прагнення підприємств до виходу з економічної кризи та стійкого економічного розвитку аналіз економічної ефективності набувас дедалі більного значення і с невід'смною фунқч епра управління. оцінювання економічної безпеки туристичного підприомсва. Охараккеризовано основні напрями визначення економічної безпеки туристичного підприємства. Запропоновано схему ефективності діяльності туристичного підприємства.

Ключові слова: туристичне підприємство, економічна безпека, методи, підходи, ефективність.

Постановка проблеми. Економічна безпека туристичного підприємства - один із актуальних напрямів досліджень економічної науки та практики управління підприємствами. Туристичний бізнес характеризується достатнім ступенем мобільності, швидкістю переорієнтації туристичних напрямів, динамічністю і гнучкістю в ухваленні рішень. Туристичні підприємства, які є здебільшого малими та середніми, оперативно реагують на зміни, краще пристосовуються до ринкової кон'юнктури, якісно і в значних обсягах задовольняють запити споживачів на туристичні послуги. В умовах конкуренції і прагнення підприємств до економічного розвитку аналіз економічної ефективності набуває дедалі більшого значення і $є$ невід'ємною функцією управління. Цей чинник наразі стає найбільш значущим, оскільки практика функціонування ринку показує, що без аналізу економічної ефективності туристичне підприємство не може нормально функціонувати. В Україні вже усвідомлено цю потребу, хоча в розвинених країнах такий аналіз $є$ нормою підприємницької діяльності тривалий час.

Аналіз останніх досліджень і публікацій. Васильців Т. для оцінювання рівня економічної безпеки підприємства використовує метод експертної оцінки, моніторинг соціально-економічних показників, аналіз й оброблення сценаріїв, оптимізацію, багатовимірний статистичний аналіз, теоретико-ігрові методи, теорію штучних нейронних мереж [1].

У роботах С. Міщенко запропоновано метод екстраполяції (екстраполяція параметричних залежностей, екстраполяція тимчасових тенденцій); експертні методи (опитування, експертні комісії, складання аналітичних доповідних записок, "мозкова атака", "Делфі"); структурно-аналітичні методи (моделювання, ієрархічна декомпозиція, морфологічний аналіз, матричний метод, мережевий аналіз, SWOT-аналіз, побудова семантичного диференціала, побудова профілю середовища, складання сценаріїв) [2]

Як свідчить аналіз сучасних підходів до трактування категорії економічної безпеки туристичних підприємств, у вітчизняній та й зарубіжній науці нара-

здобувач О.Я. Щербан - Дрогобицький ДПУ ім. Івана Франка наук. керівник: доц. Л.Г. Квасній, канд. екон. наук

2. Продуктивні сили 